\title{
The Accounting Profession Amidst the COVID-19 Pandemic
}

\author{
Sofia Papadopoulou (Corresponding author) \\ Dept. of Accounting and Finance, University of Macedonia, Greece \\ E-mail: sofpapad@uom.edu.gr \\ Maria Papadopoulou \\ Dept. of Accounting and Finance, University of Macedonia, Greece
}

Received: May 8, 2020

doi:10.5296/ijafr.v10i2.17001
Accepted: June 9, 2020

Published: June 30, 2020

URL: https://doi.org/10.5296/ijafr.v10i2.17001

\begin{abstract}
The aim of the present study is to investigate how the accounting profession in Greece has been influenced by the COVID-19 pandemic; our focus is on showcasing the ways in which the accounting professionals have adapted to emergency changes implemented in response to the pandemic, as well as the problems having potentially emerged in their professional field. Within this scope, a structured questionnaire was employed, with the sample of respondents consisting of 171 randomly selected accountants based in Greece. The results were obtained by means of descriptive and inferential statistics analysis methods. The research results showed that the COVID-19 pandemic significantly affected the activity of accounting professionals, who were forced into changes in their work routine, while, generally, experiencing difficulty in adapting to the newly emerging work demands. Finally, the research findings revealed that the importance of the accounting profession in Greece is even more pronounced during periods of emergency, when the country's economy is at risk, as the one examined.
\end{abstract}

Keywords: Accountants, COVID-19, Emergency period, Emergency changes in accounting profession, Greece

\section{Introduction}

Nowadays, the accounting profession involves the provision of a wide range of services, pertaining to the fields of accounting and finance, both to legal entities but also to individuals. 


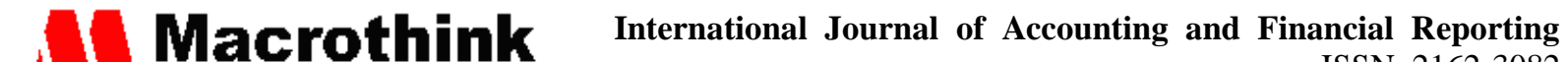 ISSN 2162-3082 2020, Vol. 10, No. 2}

This range of services may include bookkeeping, compiling financial statements, tax services, payroll services, labor and insurance support services, budgeting and reporting, as well as consulting services. Therefore, it becomes clear that the profession of an accountant is no longer limited to bookkeeping - merely involving reporting activities (Chatzoglou et al., 2011). On the contrary, the role of professionals in the accounting field has expanded to meet needs such as the analysis of past activity, the examination and evaluation of present conditions and the participation in decision-making processes with regard to future activity.

Taking into consideration all the above, the importance of the accounting profession is undoubtedly high to both businesses and individuals, but also to the state in itself and its economy. The role of professionals in the accounting field is to ensure that the professional and economic activity of both businesses and individuals is in accordance with the applicable legislation and that their clients accurately report data related to public revenue. In this way, on the one hand, macroeconomic indicators are possible to determine with accuracy, and, on the other hand, the state collects the due amount of revenue, which facilitates effective policymaking on the part of regulatory authorities, and ensures the general smooth functioning of the economy (Miller and Power, 2013).

The globalization and extrovert market policies, as well as developments taking place on a social, economic and technological basis constantly create new challenges, which modern accountants are called to face; this renders their task even more important, but, at the same time, more complex (Guthrie and Parker, 2016).

The accountants' ability to adapt to changes and meet such challenges is dependent on factors as the length of the adjustment period provided and the level of training accessible to them. However, questions arise as to how the accounting profession may be affected in cases where the state has to address emergency situations, when the daily-life routine is disrupted, and immediate action, adaptability and responsibility are called for, or, in other words, when accountants have to deal with emergency changes. The concept of emergency changes encompasses the changes required to satisfy an urgent, immediate and unexpected need, whose failure to meet would result in significant loss (William and Yarberry, 2005). Such questions are of particular importance, given the rare occurrence of such incidents in the human history - more specifically, it is for the first time in the modern history that the World Health Organization (WHO) has declared a global pandemic, which resulted in the majority of countries around the world taking emergency measures aiming both at the protection of civilians, and at the protection and support of the economy. This decision can be explained in terms of Baldwin and Weder di Mauro's (2020) suggestion that the virus may be as contagious [and destructive] economically as it is medically.

Within this context, the purpose of the present study is to investigate a number of issues, including how the accounting profession in Greece has been affected by the COVID-19 pandemic, how accountants have tried to adapt to emergency changes imposed in response to the pandemic, and which problems have occurred, potentially affecting the accountants' efficiency in their professional activity. Additionally, another goal of the present study is the examination of the role of the accountant and its significance as a key-instrument to the 


\section{Mll Macrothink}

International Journal of Accounting and Financial Reporting

ISSN 2162-3082

2020, Vol. 10, No. 2

implementation of emergency measures related to the COVID-19 outbreak, and to the support of citizens, businesses and the economy in general.

It is worth noting here that an emergency situation as the one caused by the virus outbreak is unprecedented on a world-wide scale, and that explains the limited number of similar studies found in relevant literature on a global scale. The necessity of taking emergency measures, as well as the nature of the measures itself and the degree of their implementation is determined by the competent authorities; yet, their successful implementation is largely dependent on those called to play a part in it, including, in this case, the accountants. Noteworthy is the fact that only a limited number of studies related to the accounting profession and its role - with the exception of the task and role of auditors - can be located in relevant literature. For this reason, the present study is deemed of particular significance, as it both aspires to be a valuable addition to the relevant literature, but also to be of interest to the corresponding decision-making and policy-making authorities. More specifically, the significance of the results of the present study is related to the fact that the conduct of research within the context of an actual state of emergency is possible; therefore, for the first time, feedback with regard to the management of emergency changes by accountants may be provided in real-time. At the same time, the existence of potential gaps, challenges or shortcomings, which could possibly influence the efficiency of accountants in carrying out their task within this critical period for the economy, are also investigated.

\section{The Current Situation - An Emergency Period due to the COVID-19 Outbreak}

The COVID-19 disease was first identified as a threat in December 2019 in the city of Wuhan, China. Since then, the virus has spread in countries all over the world. On January 30, the WHO declared that the COVID-19 virus represented a Public Health Emergency of International Concern (PHEIC), while the rapid spread of the virus led the WHO to declare its outbreak a pandemic on March 11, 2020. To date, 185 countries around the world have been afflicted by the pandemic and its consequences, with China, and later on, the US and Europe, being at the center of the pandemic.

The devastating impact of the virus is not solely limited to the public health section, but also becomes apparent on the level of the financial activity of the countries afflicted (Baldwin and Weder di Mauro, 2020). It is worth noting that the Organization for Economic Cooperation and Development (OECD) has, since the beginning of March, lowered its global GDP forecast to $2.4 \%$ for the year 2020, from $2.9 \%$ in 2019. For this reason, governments have prepared emergency plans and implemented support measures aiming at the minimization of the negative impact on civilians, businesses and economies in general (Fernandes, 2020). At the same time, central banks have reduced their lending rates to almost zero, and announced extensive direct subsidies to households and businesses in order to mitigate the adverse effects of COVID-19 on the economy (BIS, 2020).

It is worth mentioning that, since both the course of the pandemic and its economic impact are uncertain, the appropriateness and effectiveness of regulatory measures adopted can be deemed equally uncertain (McKibbin and Fernando, 2020). This uncertainty is understandable on the grounds that never in its modern history has the global community 
faced a similar event; therefore, no relevant studies assessing the financial impact of an emergency situation, as the one caused by the COVID-19 pandemic, are available.

More specifically, governments of countries around the world, aiming at containing the spread of the virus, have proceeded in the adoption of emergency measures, the more crucial of which involve lockdowns and curfews. These measures, in turn, have led to a reduction, or even, cessation of business activity, and a reduction or even cessation of production; at the same time, the fact that workers in many cases refrain from work has in many cases brought about a decrease in their income and even a rise in the unemployment rates. All the above seem to have led to a supply chain disruption, a drop in the consumption of various goods as well as in the demand for services, or even in shortages in products and services offered. In other words, the supply and demand balance, upon which the entire economy is based (Marshall, 1920), has been severely disrupted.

In order, then, for the impending financial impact to be mitigated to the degree possible, the governments of the afflicted countries have been taking measures in support of the economy, and providing both employees and businesses with assistance in the form of emergency benefits. According to the KPMG (2020), such support measures include, among others, the suspension of payment of tax liabilities, the subsidization of the social security contribution of employees, the financing of businesses on privileged terms, the provision of support to remote employees, the provision of subsidies to employees who have been suspended, the reduction of VAT on supply of certain goods and/or provision of services, the acceleration of refunds for income tax and VAT, and the provision of incentives encouraging job/employee retention. A further analysis of the above measures is not within the scope of the present study. Nevertheless, their extensive examination within the context of a future study is deemed crucial, so as their effectiveness could be assessed on the basis of changes in macroeconomic indicators in the corresponding countries examined.

\section{The Accounting Profession in Greece During the COVID-19 Emergency Period}

During the recent years, the accounting profession in Greece has been associated to a broader range of services - when compared to a more remote past - mainly due to the fact that a number of services previously provided by public bodies have nowadays come within the accountants' sphere of responsibility. In this respect, the enactment of the mandatory electronic filing, on the part of state services, of the tax obligations of both companies and individuals, has resulted in a sharp increase in accountants' daily tasks. More specifically, accountants in Greece, keeping up with present-day requirements, are entrusted with the daily task of filling up various types of forms and compiling statements, as well as electronically submitting them to the competent public authorities. It is obvious that all tasks carried out by accountants are to be performed with maximum accuracy; otherwise, the repercussions for clients, whether they be individuals or firms, could be severe. Simultaneously, and as stipulated by law, accountants are to be held liable for clients' misstatements provided to the state with them as intermediaries (Law No.4337, Government Gazette 129/A/17.10.2015).

In addition to all the above, the accountant in Greece is called to deal with a rapidly changing business environment: the frequent modifications in legislation and changes in the taxation 


\section{MlMacrothink}

International Journal of Accounting and Financial Reporting

ISSN 2162-3082

2020, Vol. 10, No. 2

system, in combination with pressure related to tight deadlines, on the one hand, render the accountant's task even more demanding and complex, while, on the other hand, call for the accountant's continuous and high-level training (Bruna et al., 2017). All the above render the role of the accountant - functioning as the sole link between taxpayers and the state - of paramount importance to both the economy and the society itself.

The outbreak of the COVID-19 pandemic forced the Greek government to daily announce and introduce new emergency legislative measures aiming at the support and assistance of those financially affected (Table 1). Therefore, in this case too, the accountants in Greece being the link between state-taxpayers - were the ones required to keep up to date with the new measures, to have an in-depth understanding of their content and parameters, as well as the process of their implementation, and finally, to put the measures into effect.

Therefore, during this emergency period - when the impact of the COVID-19 pandemic is not only health-related, but also poses a threat as to the entire economy of the country - the role and responsibility of accountants is of crucial importance, so that emergency measures may be of substantial benefit. Besides, no matter how many new measures are adopted, unless their proper implementation is ensured - which lies within the accountants' area of responsibility - the probability of them failing is increased.

Table 1. The main emergency measures aiming at the assistance and support of those affected by the COVID-19 in Greece

\begin{tabular}{|c|c|}
\hline Measure & Relevant Accountant Tasks \\
\hline $\begin{array}{l}\text { Businesses are entitled to suspend their employees' } \\
\text { employment contracts. }\end{array}$ & $\begin{array}{l}\text { Preparation and submission of a solemn declaration on the } \\
\text { part of the employer indicating the employees whose } \\
\text { contracts are being suspended. }\end{array}$ \\
\hline $\begin{array}{l}\text { Employees whose employment contracts have } \\
\text { been suspended are entitled to a special purpose } \\
\text { compensation of } € 800 \text { paid by the State. }\end{array}$ & $\begin{array}{l}\text { Preparation and submission of a solemn declaration on the } \\
\text { part of the employee validating their right to collect the } \\
\text { special purpose compensation fee. }\end{array}$ \\
\hline $\begin{array}{l}\text { Freelancers, self-employed individuals and } \\
\text { businesses who have been substantially affected by } \\
\text { the situation are entitled to a special purpose } \\
\text { compensation of } € 800 \text { paid by the State. }\end{array}$ & $\begin{array}{l}\text { Preparation and submission of a solemn declaration } \\
\text { validating the beneficiaries' right to collect the special } \\
\text { purpose compensation fee. }\end{array}$ \\
\hline $\begin{array}{l}\text { Employees whose employment contracts have } \\
\text { been suspended are entitled to a } 40 \% \text { reduction in } \\
\text { their main residence rent. }\end{array}$ & $\begin{array}{l}\text { Preparation and submission of a solemn declaration } \\
\text { validating the right to rent reduction. }\end{array}$ \\
\hline $\begin{array}{l}\text { Business premise rent and rent for the business use } \\
\text { of movable / immovable assets under a finance } \\
\text { lease are reduced by } 40 \% \text {. }\end{array}$ & $\begin{array}{l}\text { Preparation and submission of a solemn declaration } \\
\text { validating the beneficiaries' right to rent reduction. }\end{array}$ \\
\hline $\begin{array}{l}\text { Employees whose employment contracts have } \\
\text { been suspended are entitled to full social security } \\
\text { insurance - the social security contributions are to } \\
\text { be covered by the State. }\end{array}$ & $\begin{array}{l}\text { Preparation and submission of the analytical periodical } \\
\text { statement to the competent social insurance agency } \\
\text { validating the employee's entitlement to insurance } \\
\text { coverage by the state budget. }\end{array}$ \\
\hline
\end{tabular}




The employer is entitled to unilaterally enforce
teleworking.

Preparation and submission of a solemn declaration verifying the data of the employees receiving a special purpose leave.

Adjustment of the payroll data of those receiving a special purpose leave.

Adjustment of the data presented in the analytical periodical statement submitted to the competent social insurance body for the insurance coverage of employees receiving a special purpose leave.

Submission of a declaration form to the Labour Inspection Corps indicating the employees to be working remotely.
Provisions for the appointment of safe operation personnel and the implementation of short-time work compensation schemes (of a 6-month duration).
Submission of a declaration form to the Labour Inspection Corps indicating the employees affected by the implementation of the measure.

Adjustment of the payroll data of the employees affected by the implementation of the measure.

Adjustment of the data presented in the analytical periodical statement submitted to the competent social insurance body for the insurance coverage of employees affected by the implementation of the measure.

Grant of a repayable advance as a measure of Preparation and submission of an expression of interest assistance to businesses severely affected. form on the part of the interested party (business) / also, additional tasks not yet determined by the time the present report was drawn up.

Grant of a $€ 600$ allowance (voucher) to scientists undertaking a 100-hour distance learning program

Preparation and submission of an expression of interest form on the part of the interested party (scientist / beneficiary) with regard to their participation in the distance-learning program.

\section{Source: Greek Government Gazette}

Therefore, as a result of the COVID-19 pandemic, accountants in Greece have been called to face certain challenges and manage a number of changes. These changes may as well be characterized as emergency changes, given that the need for their implementation emerged abruptly, while their immediate being put into effect is deemed vital in addressing the crisis caused by the pandemic. In particular, one of these changes is related to the actual way accountants work; due to the lockdown and the ban on movement, but also due to the potential health hazard ensuing from accountants being in daily contact with a number of clients, they were forced to resort to remote working. However, perhaps the most important emergency change is related to the task they are called to complete: more specifically, to the emergency measures they have to put in effect under the pressure of both their clients, who must also abide by the new stipulations, but also of the state, having set strict and limited deadlines with regard to the implementation of the emergency measures. A characteristic 
example is provided by the fact that, during the period between the February 26th and the April 11th of 2020, over 190 legislative acts, Ministerial Decisions, Circulars, Explanatory Circulars and amendment decisions have been issued within the framework of COVID-19 emergency measures.

In this respect, questions are raised as to how accountants have dealt with these changes, how they have been influenced by this emergency situation, and what types of challenges they have potentially encountered in their daily duties and responsibilities. These questions fall within the scope of the present study, the results of which, being empirical, are intended to provide feedback necessary for the improvement or revision of practices and policies in the potential occurrence of similar emergency situations in the future.

\section{Research Methodology}

\subsection{Research Questions}

Taking into consideration the aim of the present research paper, the research questions arising with regard to the accounting profession in Greece during the COVID-19 emergency period are the following:

Q1: How has accountants' professional life been affected by the COVID-19 pandemic?

Q2: Was it easy for accountants to adapt to the new work demands, emerging as a result of the measures adopted by the Greek government against the spread of the COVID-19 virus?

Q3: Has the way Greek accountants work changed (from in-office to remote work), and, if yes, which were the positive and negative aspects of working remotely in the accounting profession?

Q4: Have the particularities of the legislation process and the process of implementation of emergency measures by the Greek government affected the capacity of the accountants to adapt to the new work demands?

Q5: Which are the perceptions of Greek accountants with regard to the importance of their profession within the periods before and after the appearance of COVID-19? Do they feel they receive the due amount of recognition?

\subsection{Research Tools, Sample and Data Collection}

Taking into account the research questions formulated, a structured questionnaire was designed as a research tool. A five-point Likert scale was used in the ranking and assessment of questions. It is worth noting that the questionnaire is considered to be the most appropriate tool for the conduct of quantitative research examining behavior, perceptions and attitudes (Bulmer, 2004). Additionally, the questionnaire ensures the anonymity and protection of the respondents' personal data.

The present research paper makes use of primary data collected through the use of a questionnaire, as mentioned above, during the period of the COVID-19 pandemic outbreak in Greece, that is, during April 2020. The sample size involves 171 accountants located across 


\section{Mll Macrothink}

International Journal of Accounting and Financial Reporting

ISSN 2162-3082

Greece. The sample was selected by means of the method of 'simple random sampling', while the response rate was $37 \%$. Table 2 presents the demographic characteristics of the sample used in the present study. As illustrated in Table 2, approximately $51 \%$ of the respondents participating in the survey are men and $49 \%$ are women. The majority of them are up to 35 years of age (39.8\%), while only $8.2 \%$ is over 55 years of age. Moreover, the vast majority of the respondents are holders of a bachelor degree $(65.5 \%)$ and work as self-employed accountants $(64.3 \%)$.

Table 2. Demographic characteristics of respondents

\begin{tabular}{|c|c|c|}
\hline Variables & Frequency & Percent (\%) \\
\hline \multicolumn{3}{|l|}{ Gender } \\
\hline Male & 87 & 50.9 \\
\hline Female & 84 & 49.1 \\
\hline \multicolumn{3}{|l|}{ Age Group } \\
\hline$<35$ & 68 & 39.8 \\
\hline $35-45$ & 50 & 29.2 \\
\hline $45-55$ & 39 & 22.8 \\
\hline$>55$ & 14 & 8.2 \\
\hline \multicolumn{3}{|l|}{ Educational Level } \\
\hline High School & 4 & 2.3 \\
\hline IVT & 12 & 7.0 \\
\hline $\mathrm{BSc}$ & 112 & 65.5 \\
\hline MSc & 43 & 25.1 \\
\hline \multicolumn{3}{|l|}{ Employment Status } \\
\hline Self-employed accountant & 110 & 64.3 \\
\hline Accounting Office employee & 45 & 26.3 \\
\hline Employee in company's accounting department & 16 & 9.4 \\
\hline Number of observations & 171 & \\
\hline
\end{tabular}

\subsection{Method of Data Analysis}

With the purpose to provide responses to the research questions formulated, as well as to extract reliable and accurate results, methods of descriptive and inferential statistics were employed. More specifically, the mean scores and frequencies representing the perceptions and opinions of the respondents were calculated on the grounds of a descriptive statistical analysis. Correspondingly, Wilcoxon signed-rank tests, Mann Whitney U tests, Kruskal-Wallis tests were conducted on the grounds of an inferential statistical analysis. These nonparametric tests were conducted instead of a paired sample T-test, independent samples T-test and one-way ANOVA parametric tests, because the data of variables do not meet the assumptions of the latter. Finally, a simple OLS regression analysis was conducted. Data processing was realized by means of the use of the IMB SPSS Statistics Data Editor statistical program. 


\section{Research Results}

The first part of the questionnaire concerned the investigation of the way the professional activity of accountants in Greece was affected as a result of the COVID-19 pandemic. According to the accountants participating in the research, their professional activity was severely affected (mean score 4.53), as indicated in Table 3. In particular, according to Table 3 results, the research participants expressed the opinion that every individual aspect of their professional activity was affected as a result of the pandemic.

Table 3. Mean scores of the responses with regard to changes in the professional activity of accountants related to the COVID-19 pandemic

\begin{tabular}{|c|c|c|c|c|c|}
\hline & Min & Max & Mean & S.D. & Remark \\
\hline Has COVID-19 affected your professional activity? & 1 & 5 & 4.53 & .761 & $\begin{array}{c}\text { To a great } \\
\text { extent }\end{array}$ \\
\hline Daily working hours BEFORE the COVID-19. & 4 & 19 & 8.89 & 1.845 & \\
\hline Daily working hours DURING the COVID-19. & 2 & 16 & 10.13 & 3.409 & \\
\hline Average monthly income BEFORE the COVID-19. & 345 & 20000 & 1692.44 & 1984.128 & \\
\hline Average monthly income DURING the COVID- 19. & 10 & 6000 & 881.62 & 857.271 & \\
\hline Level of work demands BEFORE the COVID- 19. & 2 & 5 & 3.94 & .760 & High \\
\hline Level of work demands DURING the COVID-19. & 1 & 5 & 4.79 & .670 & Very high \\
\hline $\begin{array}{l}\text { Level of difficulty in meeting professional deadlines } \\
\text { BEFORE the COVID- } 19 \text {. }\end{array}$ & 1 & 5 & 2.82 & 1.016 & Average \\
\hline $\begin{array}{l}\text { Level of difficulty in meeting professional deadlines } \\
\text { DURING the COVID- } 19 .\end{array}$ & 1 & 5 & 4.36 & .880 & Difficult \\
\hline Level of work-related stress BEFORE the COVID-19. & 1 & 5 & 3.39 & .856 & Average \\
\hline Level of work-related stress DURING the COVID- 19. & 2 & 5 & 4.78 & .548 & Very high \\
\hline Level of job insecurity BEFORE the COVID-19. & 1 & 5 & 2.80 & 1.100 & Average \\
\hline Level of job insecurity DURING the COVID-19. & 1 & 5 & 4.42 & .981 & High \\
\hline $\begin{array}{l}\text { Communication with associates/clients BEFORE the } \\
\text { COVID-19. }\end{array}$ & 1 & 5 & 3.93 & .892 & Good \\
\hline $\begin{array}{l}\text { Communication with associates/clients DURING the } \\
\text { COVID- } 19 .\end{array}$ & 1 & 5 & 2.78 & 1.196 & Average \\
\hline
\end{tabular}

Later on, aiming at providing an answer to the research question Q1, a nonparametric statistical Wilcoxon signed-rank test, proposed by Frank Wilcoxon (1945), was conducted in the place of a paired sample T-test, since the ordinal level data of variables of interest do not meet the assumptions of a paired sample T-test.

Based on the results of the hypothesis tests conducted (Table 4) it can be concluded that the COVID-19 outbreak and the emergency measures imposed by the Greek government changed many aspects of the accounting profession, all the Wilcoxon signed-rank tests indicating that there are major differences at a significance level 0.01 (Table 4). More specifically, accountants in Greece seem to have worked more hours daily during the COVID-19 period than before. Yet, their monthly income seems to have been reduced within the COVID-19 period. At the same time, work demands have been higher within the 


\section{MlMacrothink}

International Journal of Accounting and Financial Reporting

ISSN 2162-3082

2020, Vol. 10, No. 2

pandemic period, and accountants seem to be finding it more difficult to meet the strict deadlines set. Additionally, the results showed that work-related stress has increased among accountants during the COVID-19 period, as well as their feeling of insecurity associated to work-related issues. Finally, as the findings revealed, the quality of communication of accountants with their clients and associates seems to have been undermined.

Table 4. The results of the Wilcoxon signed-rank test with regard to the way the professional activity of Greek accountants has been affected as a result of the COVID-19

\begin{tabular}{|c|c|c|c|c|}
\hline & Null Hypothesis & $\mathbf{Z}$ & Sig. & Result \\
\hline $\mathrm{HO}_{1}$ & $\begin{array}{l}\text { No differences are observed as to the Greek accountants' working hours } \\
\text { in the periods before and during the COVID-19 outbreak. }\end{array}$ & $-4.482^{\mathrm{a}}$ & .000 & Reject \\
\hline $\mathrm{HO}_{2}$ & $\begin{array}{l}\text { No differences are observed as to the average monthly income of } \\
\text { accountants in the periods before and during the COVID-19 outbreak. }\end{array}$ & $-9.605^{b}$ & .000 & Reject \\
\hline $\mathrm{HO}_{3}$ & $\begin{array}{l}\text { No differences are observed as to the level of work demands in the } \\
\text { accounting profession in Greece in the periods before and during the } \\
\text { COVID-19 outbreak. }\end{array}$ & $-8.499^{\mathrm{a}}$ & .000 & Reject \\
\hline $\mathrm{HO}_{4}$ & $\begin{array}{l}\text { No differences are observed as to the accountants' level of difficulty in } \\
\text { meeting professional deadlines before and during the COVID-19 } \\
\text { outbreak. }\end{array}$ & $-10.053^{\mathrm{a}}$ & .000 & Reject \\
\hline $\mathrm{HO}_{5}$ & $\begin{array}{l}\text { No differences are observed as to the accountants' level of work-related } \\
\text { stress in the periods before and during the COVID-19 outbreak. }\end{array}$ & $-10.335^{a}$ & .000 & Reject \\
\hline $\mathrm{HO}_{6}$ & $\begin{array}{l}\text { No differences are observed as to the accountants' level of job insecurity } \\
\text { in the periods before and during the COVID-19 outbreak. }\end{array}$ & $-9.727^{\mathrm{a}}$ & .000 & Reject \\
\hline $\mathrm{HO}_{7}$ & $\begin{array}{l}\text { No differences are observed as to the quality of communication between } \\
\text { accountants and their clients/associates in the periods before and during } \\
\text { the COVID-19 outbreak. }\end{array}$ & $-8.690^{\mathrm{b}}$ & .000 & Reject \\
\hline
\end{tabular}

Notes: a. Based on negative ranks

b. Based on positive ranks

The second part of the questionnaire was intended to investigate the level of ease of adaptation to the new work demands on the part of the accountants, related to the emergency measures adopted by the Greek government for the containment of the COVID-19 (Q2). Based on Table 5, it becomes obvious that the research participants have attested to a high level of difficulty concerning the adaptation to the new demands; in particular, they have attested to difficulty related to the comprehension and implementation of emergency support measures related to the COVID-19 (mean score $2.28 \mathrm{\kappa al} 1.99$ respectively), as well as difficulty related to changes in the way they are called to work, as a result of the COVID-19 (mean score 2.05).

Taking into account the mean scores of these factors for each of the remarks, it was deemed necessary to introduce a new variable (ADJ) reflecting the overall level of the ease of adaptation of accountants to the new work demands, related to the COVID-19. Thus, according to the views of accountants participating in the research, their adaptation to the 


\section{Ml Macrothink}

International Journal of Accounting and Financial Reporting

ISSN 2162-3082

new work demands was deemed difficult overall (mean score 2.11). Additionally, it is worth mentioning here that the participants seem to believe that the competent state authorities and Chambers of tradesmen have not been successful in their duty to render assistance in this process of adaptation (mean score 1.73).

Table 5. Mean scores of the responses concerning the adaptation of the accountants to the new work demands as a result of the COVID-19

\begin{tabular}{lccccc}
\hline & Min & Max & Mean & S.D. & Remark \\
\hline $\begin{array}{l}\text { Ease of comprehension of the emergency measures related to the } \\
\text { COVID-19. }\end{array}$ & 1 & 5 & 2.28 & 1.059 & Difficult \\
\hline $\begin{array}{l}\text { Ease of implementation of the emergency measures related to the } \\
\text { COVID-19. }\end{array}$ & 1 & 5 & 1.99 & .898 & Difficult \\
\hline $\begin{array}{l}\text { Adaptability to work changes related to the COVID-19. } \\
\text { Have the competent state authorities/Chambers of tradesmen been of } \\
\text { assistance in the process of adaptation to changes implemented? }\end{array}$ & 1 & 5 & 1.73 & .861 & To a small \\
\hline $\begin{array}{l}\text { Ease of adapting to the new work demands related to the COVID-19 } \\
\text { (ADJ). }\end{array}$ & 1 & 5 & 2.11 & .791 & Difficult \\
\hline
\end{tabular}

At this point it was deemed necessary to examine whether the capacity of the accountants to adapt to the new work demands related to the COVID-19 differs in accordance with their demographic characteristics. For this purpose, a nonparametric statistical Kruskal-Wallis test (1952) and a nonparametric statistical Mann Witney U test (1947) were conducted, since the ordinal level data of variables of interest did not meet assumptions of the one-way ANOVA and independent samples T-test.

The findings revealed that the ease/difficulty of Greek accountants to adapt to the new work demands related to the COVID-19 does not present differences in correlation to the gender, age and educational level of accountants; in contrast, the results showed that there is statistically significant difference across the three employment status groups, estimated at a 0.05 level (Table 6). Thus, additional analyses were conducted, concerning the ease of adaptation of Greek accountants to the new work demands in correlation with the employment status group in which they belong. A statistically significant difference between self-employed accountants and employees in companies' accounting departments was observed at a 0.05 significance level (Table 6). 
Table 6. The results of the Mann Witney U tests and Kruskal-Wallis tests concerning the ease/difficulty of Greek accountants to adapt to the new work demands related to the COVID-19, in accordance with their demographic characteristics

\begin{tabular}{|c|c|c|c|c|c|}
\hline & Null Hypothesis & $\mathbf{Z}$ & Chi-Square & Sig. & Result \\
\hline $\mathrm{H}_{8}$ & $\begin{array}{l}\text { Ease of adaptation of accountants to the new work demands } \\
\text { related to the COVID-19 does not differ in correlation to } \\
\text { gender. }\end{array}$ & -.842 & - & .400 & Accept \\
\hline $\mathrm{H}_{9}$ & $\begin{array}{l}\text { Ease of adaptation of accountants to the new work demands } \\
\text { related to the COVID-19 does not differ in correlation to } \\
\text { age. }\end{array}$ & - & 3.122 & .373 & Accept \\
\hline $\mathrm{H}_{10}$ & $\begin{array}{l}\text { Ease of adaptation of accountants to the new work demands } \\
\text { related to the COVID-19 does not differ in correlation to } \\
\text { employment status. }\end{array}$ & - & 6.961 & .031 & Reject \\
\hline $\mathrm{H}_{11}$ & $\begin{array}{l}\text { Ease of adaptation of accountants to the new work demands } \\
\text { related to the COVID-19 does not differ in correlation to } \\
\text { educational level. }\end{array}$ & - & 4.324 & .229 & Accept \\
\hline $\mathrm{H}_{12}$ & $\begin{array}{l}\text { Ease of adaptation of accountants to the new work demands } \\
\text { related to the COVID-19 does not differ between } \\
\text { self-employed accountants and accounting office } \\
\text { employees. }\end{array}$ & -1.439 & - & .150 & Accept \\
\hline $\mathrm{H}_{13}$ & $\begin{array}{l}\text { Ease of adaptation of accountants to the new work demands } \\
\text { related to the COVID-19 does not present differences } \\
\text { between self-employed accountants and employees in } \\
\text { companies' accounting departments. }\end{array}$ & -2.418 & - & .016 & Reject \\
\hline $\mathrm{H}_{14}$ & $\begin{array}{l}\text { Ease of adaptation of accountants to the new work demands } \\
\text { related to the COVID-19 does not present differences } \\
\text { between accounting office employees and employees in } \\
\text { companies' accounting departments. }\end{array}$ & -1.467 & - & .142 & Accept \\
\hline
\end{tabular}

Next, the third part of the questionnaire was developed so as to examine whether accountants in Greece started working remotely as a result of the COVID-19, as well as to identify the potential positive and negative impact of working remotely in the accounting profession, according to the opinions of the respondents (Q3). Table 7 shows that rarely did the accountants participating in the survey work remotely before the COVID-19 outbreak (mean score 1.81); additionally, as a result of the COVID-19, they have currently turned to remote working, to which they resort more often than was the case in the past, yet, still to an average degree (mean score 3.39). Moreover, the accountants participating in the research expressed the opinion that working remotely has had a negative impact on the time required for the completion of their tasks, the communication and professional relationship with their clients, work-related stress and income (Table 7). 
Table 7. Mean scores of the responses concerning accountants' working remotely as a result of the COVID-19

\begin{tabular}{lcccccc}
\hline & Min & Max & Mean & S.D. & Remark \\
\hline $\begin{array}{l}\text { Did you use to work remotely BEFORE the COVID-19 } \\
\text { outbreak? }\end{array}$ & 5 & 1.81 & .966 & Rarely \\
\hline $\begin{array}{l}\text { Have you been working remotely DURING the COVID-19 } \\
\text { outbreak? }\end{array}$ & 1 & 5 & 3.39 & 1.428 & To a medium \\
Impact of working remotely on working hours (duration). & 1 & 5 & 2.47 & 1.118 & Negative \\
\hline Impact of working remotely on working hours' flexibility. & 1 & 5 & 3.31 & 1.233 & None \\
\hline Impact of working remotely on communication with clients. & 1 & 5 & 2.30 & .977 & Negative \\
\hline Impact of working remotely on relationship with clients. & 1 & 5 & 2.31 & .941 & Negative \\
\hline Impact of working remotely on work-related stress, & 1 & 5 & 2.43 & 1.217 & Negative \\
\hline Impact of working remotely on work-related costs. & 1 & 5 & 2.65 & 1.233 & None \\
\hline Impact of working remotely on income. & 1 & 5 & 2.03 & .948 & Negative \\
\hline Impact of working remotely on quality of work produced. & 1 & 5 & 2.58 & 1.121 & None \\
\hline
\end{tabular}

In addition to that, and based on the Table 8 results, the majority of the accountants participating in the survey expressed the opinion that, while they had access themselves to the means necessary to carry out their tasks and activities remotely, the same was not true of all their clients. Moreover, the vast majority $(84.2 \%)$ of the respondents stated that they would not be able to carry out their entire range of accounting activities on the basis of remotely working in non-emergency situations.

Table 8. Frequencies of responses concerning the parameters rendering working remotely possible

\begin{tabular}{lccc}
\hline & Response & Frequency & Percent \\
& & $(\%)$ \\
\hline I have access to all the means necessary for working remotely. & Yes & 119 & 69.6 \\
& No & 52 & 30.4 \\
\cline { 2 - 4 } All my clients have access to the means necessary for me to be able to & Yes & 14 & 8.2 \\
carry out my tasks/activities remotely. & No & 157 & 91.8 \\
\cline { 2 - 4 } I can carry out the entire range of my professional activities remotely, & Yes & 27 & 15.8 \\
irrespectively of the COVID-19. & No & 144 & 84.2 \\
\hline
\end{tabular}

The fact that the COVID-19 pandemic outbreak affected the accountants' way of working, as suggested by the survey participants, is also confirmed by the results of the nonparametric statistical Wilcoxon signed-rank test (Table 9). The findings showed that the Greek accountants have been working remotely on a much more frequent basis during the COVID-19 outbreak than before, as revealed by a significant difference at a significance level 0.01. 
Table 9. The results of the Wilcoxon signed-rank test concerning the implementation of a remote work policy before and during the COVID-19

\begin{tabular}{llcc}
\hline Null Hypothesis & Z & Sig. & Result \\
\hline $\mathrm{H}_{15} \quad \begin{array}{l}\text { The frequency of the implementation of a remote work policy on the part } \\
\text { of Greek accountants does not present differences in the periods before } \\
\text { and during the COVID-19. }\end{array}$ & $-9.818^{\mathrm{a}}$ & .000 & Reject \\
\end{tabular}

Note: a. Based on negative ranks

The fourth part of the questionnaire called the respondents to assess the individual aspects comprising the sum of the tasks they were called to carry out with regard to the implementation of emergency measures decided by the Greek government. Thus, as illustrated by the results of Table 10, and according to the research participants, the statutes and directives concerning the content and the implementation of emergency measures related to the COVID-19 were not sufficiently clear and comprehensible - with regard to way they were formulated - (mean score 1.74); at the same time, the accountants' cooperation with the competent bodies and services was assessed as unsatisfactory (mean score 1.67), as was the information, guidance and support provided by them (mean score 1.63). Apart from that, the research participants expressed the opinion that they were neither provided with timely, clear and detailed guidelines (mean score 1.61), nor with a reasonable timeframe (mean score 1.57) that would allow the proper implementation of the emergency measures. Additionally, and taking into consideration the mean score of the values pertaining to each opinion expressed, it was deemed necessary to introduce a new variable $(\mathrm{MNG})$ reflecting the degree to which the accountants' task - with regard to the proper implementation of the emergency support measures - is manageable on their part. The particularly low mean score of this variable (mean score 1.70) reflects the respondents' perception of this task as difficult to manage.

Table 10. Mean scores of the responses concerning the aspects comprising the overall task of Greek accountants with regard to the implementation of the emergency COVID-19 support measures

\begin{tabular}{lccccc}
\hline & Min Max & Mean & S.D. & Remark \\
\hline $\begin{array}{l}\text { The emergency measures have been formulated in a clear, detailed and } \\
\text { comprehensible way. }\end{array}$ & 1 & 5 & 1.74 & .960 & Disagree \\
\hline $\begin{array}{l}\text { Clear and detailed guidelines have timely been provided as to the } \\
\text { implementation of the emergency measures. }\end{array}$ & & 5 & 1.61 & .929 & Disagree \\
\hline
\end{tabular}

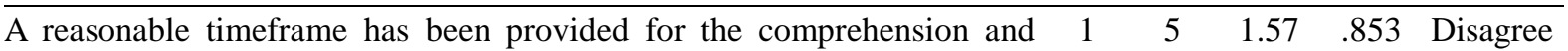
proper implementation of the emergency measures.

Adequate information, guidance and support has been provided for the $\begin{array}{llllll}1 & 5 & 1.63 & .907 & \text { Disagree }\end{array}$ proper implementation of the emergency measures.

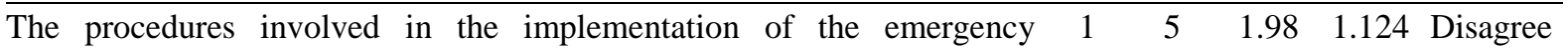
measures are simple and not subject to bureaucracy.

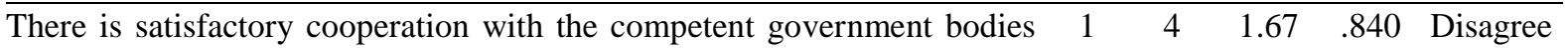
and services.

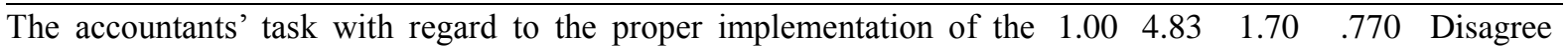
emergency measures was easy to manage (MNG).

Later on, aiming at establishing whether the task the accountants were called to carry out - 


\section{Mll Macrothink}

International Journal of Accounting and Financial Reporting

ISSN 2162-3082

2020, Vol. 10, No. 2

with regard to the emergency COVID-19 support measures taken by the government - has influenced their capacity to adapt to the newly emerging work demands (Q4), a simple regression analysis was applied through the Ordinary Least Square method. The regression results (Table 11) revealed a statistically significant relationship between the accountants' capacity to adapt to the new work demands and the degree of manageability of the task they were called to carry out, estimated at a 0.01 significance level.

Table 11. Simple OLS regression

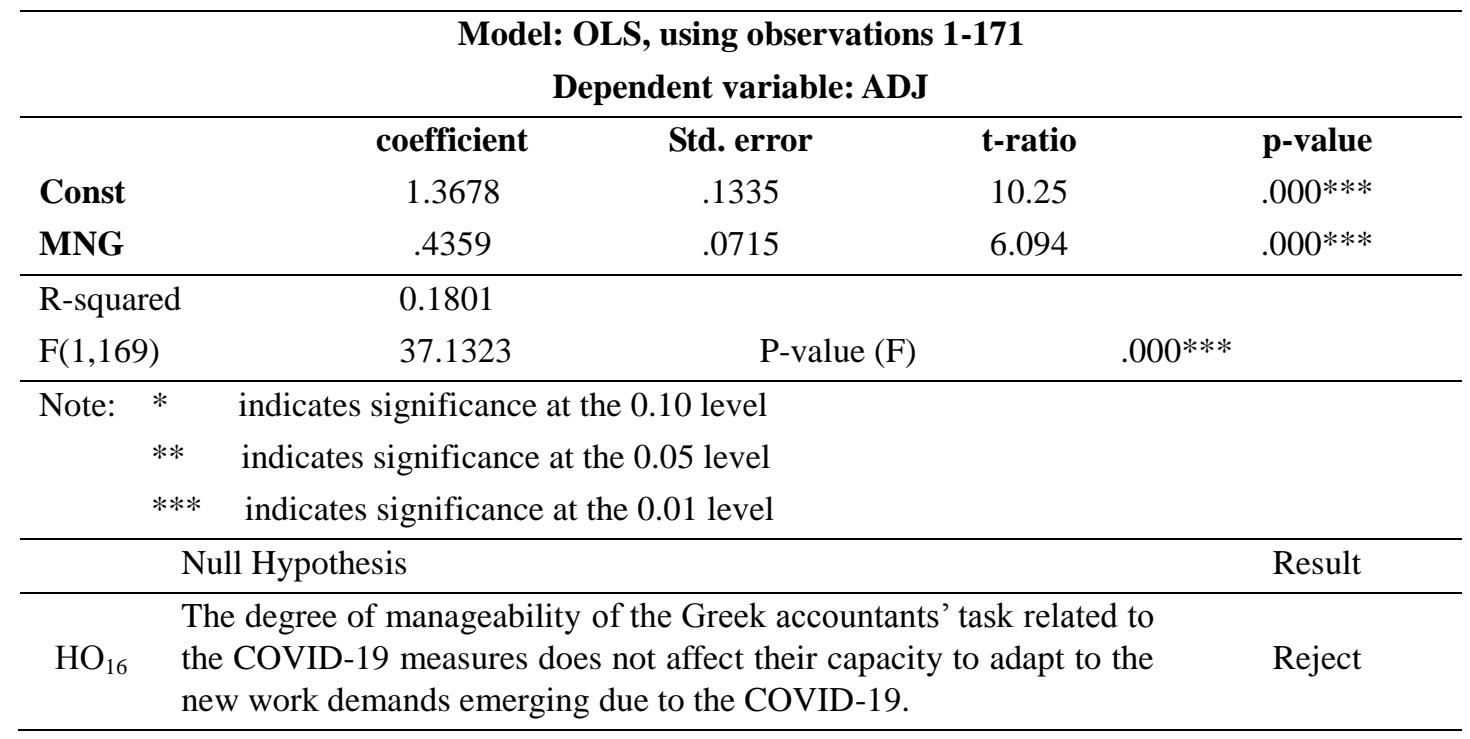

Finally, the last part of the questionnaire was intended to investigate the role and importance of the accounting profession. In particular, as illustrated in Table 12, the accountants participating in the survey appeared to view the accounting profession as of crucial importance in emergency periods as the COVID-19 one (mean score 4.59). On the contrary, the same participants stated that, before the COVID-19 outbreak, they perceived the accounting profession as of high, but not crucial, importance as to the state, the businesses, the employees and the country's economy in general (mean score 4.46). Despite the crucial role of the accounting profession, the accountants participating in the survey seemed to believe that they do not receive the due recognition by the state and their clients, either in the form of an economic reward (mean score 1.93) or in the form of moral satisfaction (mean score 2.11).

Table 12. Mean scores of the responses concerning accountants' beliefs as to the importance of the accounting profession and its recognition

\begin{tabular}{lccccc}
\hline $\begin{array}{l}\text { The accounting profession is of crucial importance in emergency } \\
\text { periods, as the period of the COVID-19 outbreak. }\end{array}$ & 1 & 5 & 4.59 & .664 & $\begin{array}{c}\text { Strongly } \\
\text { Agree }\end{array}$ \\
\hline $\begin{array}{l}\text { Did you perceive the accounting profession as of crucial importance } \\
\text { before the COVID-19 outbreak? }\end{array}$ & 1 & 5 & 4.46 & .668 & Agree \\
\hline $\begin{array}{l}\text { Do you receive the treatment and recognition you believe you deserve } \\
\text { on an economic level? }\end{array}$ & 1 & 4 & 1.93 & .722 & Disagree \\
\hline $\begin{array}{l}\text { Do you receive the treatment and recognition you believe you deserve } \\
\text { on the level of moral satisfaction? }\end{array}$ & 1 & 4 & 2.11 & .843 & Disagree \\
\hline
\end{tabular}




\section{$\Lambda$ Macrothink}

International Journal of Accounting and Financial Reporting

ISSN 2162-3082

Subsequently, and aiming at providing an answer to the research question Q5, a nonparametric statistical Wilcoxon signed-rank test was conducted in the place of a paired sample T-test, since the ordinal level data of the variables of interest did not meet the assumptions of the paired sample T-test. Based on the results of the hypothesis test (Table 13), it can be concluded that during the emergency period Greece is still going through, related to the COVID-19 pandemic, the Greek accountants' perceptions as to the role and the importance of their profession present differences at a significance level 0.01 (as to their perceptions before the COVID-19 pandemic). In addition to that, the results of the test lead to the conclusion that Greek accountants assess the role and the importance of their profession as being of higher significance to the state, the businesses, the employees, and, generally, the country's economy, than was the case before the COVID-19 outbreak.

Table 13. The results of the Wilcoxon signed-rank test concerning accountants' perceptions as to the role and importance of their profession before and after the COVID-19

\begin{tabular}{lllll}
\hline Null Hypothesis & $\mathbf{Z}$ & Sig. & Result \\
\hline The accountants' perceptions as to the role and importance & & & \\
of their profession to the state, the businesses, the & & & \\
$\mathrm{H}_{17}$ & $\begin{array}{l}\text { employees and the country's economy in general do not }-2.727^{\mathrm{a}} \\
\text { differ in the periods before and during the COVID-19 } \\
\text { outbreak. }\end{array}$ & & & Reject \\
\end{tabular}

Notes: a. Based on negative ranks

\section{Discussion}

Based on the empirical results of the analysis presented above, it becomes clear that the COVID-19 pandemic has had an impact on various aspects of the accounting profession in Greece. More specifically, the findings showed that work demands have been increased in the accounting profession $\left(\mathrm{HO}_{3}\right)$ as a result of the new emergency measures adopted by the Greek government with regard to the COVID-19, which, accountants were called to implement, functioning as a link between the government and taxpayers. This fact, in combination with the short and strict deadlines the accountants were called to abide by in the process of implementation of the measures $\left(\mathrm{HO}_{4}\right)$, has forced Greek accountants to increase their working hours within the COVID-19 outbreak period; paradoxically, though, not only did their income not increase correspondingly, but instead it seems to have significantly decreased $\left(\mathrm{HO}_{2}\right)$. This is likely due to the fact that the majority of businesses either suspended their operations in accordance with the mandate issued by the government, or significantly limited their activities, which resulted in a reduction in turnover, and, subsequently, in their temporary inability to meet their obligations.

At the same time, the pressure exerted as to the immediate and proper implementation of emergency measures related to the COVID-19 resulted in increased levels of job insecurity $\left(\mathrm{HO}_{6}\right)$ experienced by the Greek accountants, as well as in an increase in the levels of job-related stress $\left(\mathrm{HO}_{5}\right)$, in comparison to the pre-COVID-19 era.

It therefore becomes apparent that the challenges posed to the Greek accountants, arising as the consequence of the emergency measures taken for the containment of the pandemic, were 


\section{MlMacrothink}

International Journal of Accounting and Financial Reporting

ISSN 2162-3082

2020, Vol. 10, No. 2

significant; moreover, the accountants had to promptly adapt to all emergency changes, aiming at meeting the newly emerging work demands. This process of adaptation was characterized as 'difficult', according to the accountants participating in the survey (Table 5). Nevertheless, the findings revealed that the employees in companies' accounting departments found it easier to adapt to changes in comparison to the self-employed accountants $\left(\mathrm{HO}_{8}-\mathrm{H}_{14}\right)$. This finding is not surprising, given that self-employed accountants serve the needs of a large number of clients, both firms and individuals, not sharing the same characteristics and demands, but whose needs had to be covered immediately. Plus, it is usual for the majority of small and medium-sized businesses in Greece to cooperate with self-employed accountants as external associates, who, being in charge of accounting units or offices, were in this case the ones to shoulder the largest part of responsibility related to emergency changes.

One of the main reasons why Greek accountants faced difficulty in adapting to the new work demands was related to the change from in-office working to remotely working, brought about as a consequence of the precaution measures adopted against the spread of the COVID-19 $\left(\mathrm{H}_{15}\right)$. According to the majority of the accountants participating in the survey, while they stated that they had access to all the means/tools necessary in remote work themselves, their clients in many cases lacked the necessary equipment that would render it possible; hence, they stated that they would be unable to handle their entire range of activities remotely within periods not flagged as 'emergency' (Table 8). The results also showed that even the quality of communication of Greek accountants with their clients and associates has been negatively affected during the period under examination $\left(\mathrm{H}_{7}\right)$, a fact potentially related to distance communication in itself. Additionally, according to the respondents, remotely working in the accounting profession has had a negative impact on the number of working hours of accountants per day, on their communication and relationship with clients, on the level of work-related stress, as well as on their income (Table 7).

As already mentioned, Greek accountants, apart from their usual professional activities, during the period of the COVID-19 outbreak were also called to implement a series of emergency measures directed at the support of taxpayers, businesses and individuals affected by the pandemic; these measures were legislated by the government from scratch, while their implementation was designated as urgent. However, in order for the proper implementation of the measures to be possible and exempt from errors or omissions, the fulfillment of certain conditions would be deemed necessary; such conditions involve the precise, detailed and comprehensible formulation of the measures, the timely provision of clear and comprehensive guidelines concerning the implementation of measures, the planning of simple processes for their implementation, the provision of a reasonable timeframe allowing their comprehension and proper implementation and, finally, the cooperation with the competent government bodies and services, which should be of assistance during the period of duration of the measures.

The accountants participating in the survey stated that all the conditions mentioned above were fulfilled to a small extent, a fact hindering their task with regard to the proper implementation of the emergency COVID-19 measures and rendering it more difficult to 


\section{MlMacrothink}

International Journal of Accounting and Financial Reporting

ISSN 2162-3082

2020, Vol. 10, No. 2

manage (Table 10). It is also important that the same parameters had a significant negative impact on the capacity of Greek accountants to adapt to the new work demands $\left(\mathrm{H}_{16}\right)$ as well.

Finally, the results of the present study confirm the importance of the role and the significance of the accounting profession in Greece, which appear to have been even more pronounced amidst the COVID-19 pandemic $\left(\mathrm{H}_{17}\right)$. This is due to the fact that accountants in Greece assume the role of a 'link' between the state and taxpayers, and, as such, they have played a vital role in the implementation of the emergency measures aimed at the support of those affected within the period of the COVID-19 pandemic. To the state, accountants have been the executive instrument in charge with the implementation of the measures, while, to the taxpayers, both businesses and individuals, they have functioned as the means for them to have access to the financial benefits provided as assistance within this challenging period.

All this, in combination with the non-cessation of the accountants' professional activity due to the need for catering for the current - usual - needs and obligations of the taxpayers, indirectly contributed in the support of the country's economy during this period of crisis. Nevertheless, despite the fact that the importance of the accounting profession, especially within the COVID-19 pandemic period, has been highlighted, the accountants participating in the survey suggested that they have not received an equivalent amount of recognition, either on an economic level, or in the form of an ethical reward (Table 12).

\section{Conclusion}

During this - unprecedented - period of emergency related to the COVID-19 outbreak, the doctors, nurses and the entire health-care personnel are undoubtedly those in the forefront of the battle against the pandemic, struggling daily to minimize human loss - much like those responsible for the supply of goods. However, as also previously discussed, the loss ensuing from the COVID-19 pandemic is not solely limited to the health sector, given that its implications in the financial sector are also expected to be significant. For this reason, the Greek government appropriately and in a timely manner announced and adopted emergency measures aiming at strengthening the country' economy; an already stricken economy, which only started to exhibit its first signs of recovery from the precedent financial crisis in 2019 (Stournaras, 2019).

The accountant in Greece, being the sole link between the state and the taxpayers, has undertaken the task of the implementation of these emergency measures as an instrument of support to the state effort for the avoidance of the private sector financial collapse. Therefore, the role of the accounting profession and its importance is a lot starker in the context of this emergency period. Taking into consideration the results of the present study, the accountants in Greece have made their own effort, devoting more time to their professional activities without remuneration, under particularly adverse conditions of time pressure, work-related stress, anxiety and insecurity.

In addition to that, the findings of the present research paper have pointed to the difficulty experienced by Greek accountants in adapting to the new work demands, mostly related to 
two parameters. The first parameter involves the change in the way of working of accountants, who resorted to working remotely. Although accountants stated that they had access to the necessary tools that would allow them to work remotely, the same was not true of their clients, a fact posing obstacles to them carrying out their professional activities. At this point, the issue of the accessibility of new technologies by everyone comes up, in an era when technology evolves rapidly and one could reap significant benefits from its use - especially in emergency periods as the current one. It would therefore be crucial that, after the end of the pandemic, all businesses and traders be provided with incentives encouraging their familiarization and equipment with novel technologies; thus, even if they prefer not to resort to their implementation under normal circumstances, they would still be prepared to cope with the demands of any similar emergency situations in the future. The second parameter involves the manageability of the Greek accountants' task and the difficulties experienced with regard to the implementation of the emergency support measures taken by the government.

Hence, the current empirical study could provide feedback to the competent state authorities, so that in the likelihood of a similar future event, and with regard to the planning of emergency measures, they would be able to focus on the individual aspects presenting weaknesses as to their implementation; that would, in turn, facilitate the accountant's task, and, by extension, ensure the proper, and free-from-errors and omissions, implementation of measures.

In conclusion, the present study is the first in the worldwide literature to put the accounting profession under the microscope amidst an emergency period, as the one related to the COVID-19 pandemic. The present work could also incite the interest of other researchers into investigating any corresponding challenges, changes, but also potential concerns having risen with regard to the accounting profession, as a result of the COVID-19, in other countries afflicted by the pandemic. In such a case, comparative results could also be drawn, that could enrich the international literature resources and would be of even greater interest to the respective regulative authorities. Finally, taking into account both the findings of the present study, but also the lack of relevant literature on a worldwide scale, the conduct of future studies concerning the profession of the accountant (not involving audit work) is deemed necessary; and especially, when taking into consideration the fact that the accounting profession is subject to a regime of continuous assessment and compliance with the ever-changing environment, which renders its nature even more complex.

\section{References}

Baldwin, R., \& Weder di Mauro, B. (2020). Economics in the time of COVID-19. A VoxEU.org Book, CEPR Press, London.

Bruna, I., Senkus, K., Subaciene, R., \& Sneidere, R. (2017). Evaluation of perception of Accountant's role at the enterprise in Latvia and Lithuania. European Research Studies Journal, XX (3A), 143-163. https://doi.org/10.35808/ersj/701

Bulmer, M. (2004). Questionnaires (1st ed.). Thousand Oaks, United States: SAGE 
Publications Inc.

Chatzoglou, P. D., Vraimaki, E., Komsiou, E., Polychrou, E., Diamantidis, A. D. (2011). Factors affecting accountants' job satisfaction and turnover intentions: A structural equation model. In 8th International Conference on Enterprise Systems, Accounting and Logistics (8th ICESAL 2011), Thassos Island, Greece, pp. 130-147.

Fernandes, N. (2020). Economic effects of coronavirus outbreak (COVID-19) on the world economy. SSRN Electronic Journal. https://doi.org/10.2139/ssrn.3557504

Wilcoxon, F. (1945). Individual comparisons by ranking methods. Biometrics Bulletin, 6(1), 80-83.

Guthrie, J., \& Parker, L. D. (2016). Whither the accounting profession, accountants and accounting researchers? Commentary and projections. Accounting Auditing \& Accountability Journal, 29(1), 2-10. https://doi.org/10.1108/AAAJ-10-2015-2263

Kruskal, W. H., \& Wallis, W. A. (1952). Use of ranks in one-criterion variance analysis. Journal of the American Statistical Association, (47), 583-621.

Mann, H. B., \& Whitney, D. R. (1947). On a test of whether one of two random variables is stochastically larger than the other. Annals of Mathematical Statistics, (18), 50-60.

Marshall, A. (1920). Principles of economics (8th ed.). London: Macmillan and Co.

McKibbin, W. J., \& Fernando, R. (2020). The global macroeconomic impacts of COVID-19: Seven scenarios. SSRN Electronic Journal. https://doi.org/10.2139/ssrn.3547729

Miller, P., Power, M. (2013). Accounting, organizing, and economizing: Connecting accounting research and organization theory. Academy of Management Annals, 7(1), 557-605. https://doi.org/10.5465/19416520.2013.783668

Stournaras, Y. (2019). Lessons from the Greek Crisis: Past, Present, Future. Atlantic Economic Journal, 47(2), 127-135. https://doi.org/10.1007/s11293-019-09615-8

William, A., \& Yarberry, J. (2005). Change Management. EDPACS: The EDP Audit, Control,

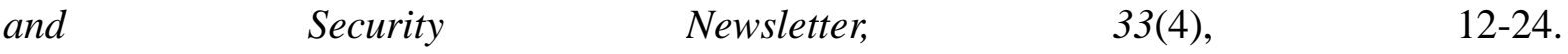
https://doi.org/10.1201/1079.07366981/45519.33.4.20051001/90024.3

World Health Organization (WHO). (2020, January 30). Statement on the second Meeting of the International health regulations (2005) emergency committee regarding the outbreak of novel coronavirus (2019-nCoV). Retrieved from https://www.who.int/news-room/detail/30-01-2020-statement-on-the-second-meeting-of-the-i nternational-health-regulations-(2005)-emergency-committee-regarding-the-outbreak-of-nove 1-coronavirus-(2019-ncov)

OECD. (2020, 2 March). Global economy faces gravest threat since the crisis as coronavirus spreads. $\quad$ Retrieved from http://www.oecd.org/economy/global-economy-faces-gravest-threatsince-the-crisis-as-corona virus-spreads.htm 


\section{Macrothink \\ International Journal of Accounting and Financial Reporting ISSN 2162-3082 2020, Vol. 10, No. 2}

World Health Organization (WHO). (2020, March 11). WHO director-general's opening remarks at the media briefing on COVID-19. Retrieved from https://www.who.int/dg/speeches/detail/who-director-general-s-opening-remarks-at-the-medi a-briefing-on-covid-19---11-march-2020

Bank for International Settlements (BIS). (2020, April). Measures to reflect the impact of COVID-19. Basel Committee on Banking Supervision.

KPMG. (2020, April 7). COVID-19 Global Tax Developments Summary. Retrieved from https://assets.kpmg/content/dam/kpmg/us/pdf/2020/03/covid-19-tax-developments-summary. pdf

\section{Copyright Disclaimer}

Copyright for this article is retained by the author(s), with first publication rights granted to the journal.

This is an open-access article distributed under the terms and conditions of the Creative Commons Attribution license (http://creativecommons.org/licenses/by/4.0/) 